\title{
THE REPUBLIC OF SERBIA AND THE BELT AND ROAD INITIATIVE
}

\author{
https:/ / doi.org/10.18485/iipe_balkans_rssc.2020.ch17
}

\begin{abstract}
In 2013, President of the People's Republic of China, Xi Jinping, launched the One Belt One Road Initiative, later abbreviated as the Belt and Road Initiative. Surprisingly or not, the initiative became widely accepted. The Republic of Serbia was among the countries that warmly welcomed it and decided to join. This article gives an insight into the results that Serbia has achieved participating in this initiative so far. Besides, the author tried to determine if this political decision had influenced the Republic of Serbia's position in international relations and if it did to what extent. Although the BRI was launched in 2013, the time context of this paper starts earlier in order not to neglect Serbia and China's bilateral relations that have been ascending for decades. The quality of their relations was never conditioned by undeniable disproportion in population, territory or economic strength. Their linkage was based on mutual understanding and respect for the international law norms and principles.

Keywords: The Republic of Serbia, The People's Republic of China (PRC), the Belt and Road Initiative (BRI), 17+1 form of cooperation, multilateralism, international relations, international law.
\end{abstract}

\section{INTRODUCTION}

When speaking about the quality of bilateral relations between countries, one would usually claim that it is conditioned either by territorial closeness, belonging to the same civilization, or at least similarities in the size of territory and/or population. Nevertheless, in practice, distinctive cases might be found. Such is the case of the People's Republic of China (PRC) and the Republic of Serbia. These two countries and their bilateral relations are an

\footnotetext{
${ }^{1}$ Research Fellow, Institute of International Politics and Economics, Belgrade, Serbia. E-mail: ivona@diplomacy.bg.ac.rs.

${ }^{2}$ The paper presents findings of a study developed as a part of the research project "Serbia and challenges in international relations in 2020", financed by the Ministry of Education, Science, and Technological Development of the Republic of Serbia, and conducted by Institute of International Politics and Economics, Belgrade.
} 
example proving that even in the case when none of the factors given above are existent, political relations may be at the highest level.

However, one should not jump into the conclusion that it has been the case ever since. Although the then Socialist Federal Republic of Yugoslavia (SFRY) of which Serbia was one of the constituent republics recognized the People's Republic of China immediately after its proclamation in 1949, the two countries established its relations in January 1955. ${ }^{3}$ The reason for this postponing was ideological and directly connected with a position towards the then Union of Soviet Socialist Republics (USSR), which highlights the influence of the changing nature of the world in this regard. (Petranović, 1988). Practically, that meant that the Communist Party of China (CPC), or the Chinese government, during the well-known Informbiro case when Yugoslavia openly opposed USSR, supported Moscow.

The situation changed when China started nurturing aspiration to become both the most influential state and the communist party in its own sphere of influence. A particular problem appeared when Moscow realized that such a sphere tended to include not only the Asian countries but even European ones. ${ }^{4}$ Distance between Beijing and Moscow was constantly growing.

Knowing this, the process of the warming up of relations with Yugoslavia was not surprising - it was expected. Yugoslavia, or Tito, led wise politics. As one of the prominent leaders of the Non-Alignment Movement, during the Brioni islands meeting, Yugoslavia initiated a declaration aimed to support China's application to join the Organization of the United Nations (OUN) (Petranović, 1988, p. 372).

Equally important for the development of further relations and particularly their quality was that the two countries shared principles of international law and peaceful coexistence. The decades that followed and further development of overall international relations proved the thesis given above. Processes that started to unstoppable convert once bipolar world order and the diminishing of the communist block significantly affected relations between Serbia and China (Obradović, 2016, p. 125). The

\footnotetext{
${ }^{3}$ After the dissolution of the Socialist Federal Republic of Yugoslavia, several new states were formed. First, the Federal Republic of Yugoslavia (FRY), then the State Union of Serbia and Montenegro and finally, in 2006, the Republic of Serbia. These changes have never affected bilateral relations between Serbia and China. China treats Serbia as the successor state of the former SFRY, which in terms of international law means one-sided Chinese recognition of the international law subjectivity of the former Yugoslavia.

${ }^{4}$ Albania, for instance.
} 
most significant event that created milestones in China's and Serbia's relations was the case of the severe breaching of international law and illegal bombing of the FR Yugoslavia in 1999. Namely, on 7 May 1999, one of the NATO missiles hit the Chinese Embassy in Belgrade and killed three Chinese journalists while 20 of the employees were wounded.

The diplomatic battle that the two countries, together with the Russian Federation (RF) led at the international stage, especially within the OUN, made their mutual connections even tighter. Formalization of this ascending direction was the signing of agreements aimed to create strategic partnerships.

\section{SINO - SERBIAN RELATIONS IN THE 2000s}

The big change in Serbia's foreign policy happened after 5 October and the fall of Slobodan Milošević. Newly formed government push its effort in renewing cooperation with the European Union (EU), setting the accession to this organization as a sine qua non of the country's future and Serbian citizens' prosperity (Lađevac, 2008).

The beginning of the process of normalization of relations, renewal of political dialogue and cooperation with the EU was symbolized by the first visit of the President of FRY, Dr. Vojislav Kostunica, to the Biarritz European Council on 12 October 2000 (Lađevac, 2008, p. 59). A month later, Serbia-EU relations were institutionalized by signing the Framework Agreement for the implementation of EU assistance and support programs for the FRY. In this manner, the FRY accessed to the Stabilization and Association Process, which was expected to be finalized with achieving full EU membership. ${ }^{5}$

Unfortunately, in the forthcoming period, Serbia faced many problems that heavily burdened its relations with the EU. In the beginning, it was the problem regarding the existing relationship between Serbia and Montenegro as federal units of the FRY. Their relations were severely disrupted during 1998 and 1999, and contrary to expectations, after the October changes in 2000, the situation in the mutual relations between the two republics was not improved, but it worsened. Finally, two republics split apart after the referendum held in Montenegro in 2006.

The second problem was Serbian (non)cooperation with the International Criminal Tribunal for the former Yugoslavia or the Hague Tribunal. This

\footnotetext{
${ }^{5}$ The Stabilization and Association Process (SAP) is the European Union's policy towards the Western Balkans, established with the aim of eventual EU membership. The SAP was launched in June 1999 and strengthened at the Thessaloniki Summit in June 2003.
} 
problem even caused the decision of the EU Council of Ministers to suspend negotiations with Serbia (Lađevac, 2008, p. 62). Subsequently, the negotiations were resumed on 13 June 2007, and the signing of the agreement was expected by the end of the year. However, as the negotiations on the status of Kosovo and Metohija went further, new problems began to emerge. The first crisis occurred when the EU decided to send its mission to the territory of Kosovo and Metohija. Tensions have continued to grow after the unilateral declaration of Kosovo's independence on 17 February 2008. The problem got even bigger when a certain number of the EU member states decided to recognize this 'country'. However, both the EU and Serbia, on each side, have made great efforts in trying to overcome this crisis. The diplomatic activity was not without results, so the Stabilization and Association Agreement (SAA) was finally signed on 29 April 2008 (Lađevac, 2008b, p. 13).

Unfortunately, it was not a 'happy ending' story for Serbia on its European path. Not only that Serbia faced the full meaning of the conditionality politics or colloquially speaking stick and carrot method, but it even had a problem more - a problem that was unknown to the previous pre-accession countries. The year 2008 brought the world economic crisis that severely hit not only all countries, but the world financial system as a whole.

Suddenly, Serbia could not be granted the European funds planned to be invested in the economy devastated for decades. At that point, Serbia was forced to make changes that were necessary to revive the economy and improve the living standard of its citizens.

Based on several decades-long excellent relations, Serbia and China decided to further improve them by signing the Agreement on Comprehensive Strategic Partnership. This document was signed during the visit to Bejing of the then Serbian President, Boris Tadić, in August 2009. In the Joint Statement signed by the Chinese President $\mathrm{Hu}$ and Serbian Tadić, the commitment to each other's basic national goals was expressed (Joint Statement, 2009). Serbia reaffirmed its commitment to the One-China policy and opposition to 'Taiwan independence'. China reaffirmed its respect for the sovereignty and territorial integrity of Serbia and fully upheld the official Serbian stance on the secession of Kosovo from Serbia.

Shortly after the establishment of the strategic relationship with China, President Tadić defined the substantial shift in Belgrade's foreign policy that has been captured in the innovative 'four pillars of diplomacy' doctrine (Petrović and Đukanović, 2012). To accommodate the strategic partnership and reflect China's importance for Serbia, Beijing was placed on the list already containing Brussels, Moscow and Washington as the major 
international places of reference for Serbia. On the other hand, strategic partnership meant that Serbia became China's only strategic partner in Southeast Europe.

Based on the strategic partnership, the two countries elaborated a fourpoint proposal on developing the Sino-Serbian strategic relationship $(\mathrm{Hu}$ Jintao, 2009). Firstly, there was a need to have more political exchanges. President Hu said the two sides should maintain high-level exchanges, promote inter-governmental, inter-parliamentary and inter-party exchanges and cooperation. Secondly, there was a need to increase economic and trade exchanges. In that respect, both sides should take joint measures to actively tap the potential, cultivate new growth points, maintain the sustained and stable development of bilateral trade and gradually improve the trade balance in the development process. There were several fields indicated as the fields of special interest in which China was willing to enhance cooperation with Serbia. Those were the fields of infrastructure, petrochemicals, energy, and high-technology. Thirdly, enhancing peopleto-people exchanges in areas of culture, education, health, sports, science, technology and tourism. Special encouragement should be given to the youths, non-governmental groups and local governments in order to carry out exchange activities in various forms in a bid to enrich bilateral ties. Finally, the fourth was a proposal to strengthen multilateral cooperation.

As this formal precondition was fulfilled, the intense diplomatic activity followed in order to boost trade and investment relations between China and Serbia. Numerous delegations started to be exchanged and high officials' forums or meetings started to be organized frequently.

Not only that Belgrade authorities promoted Serbian economic environment as friendly and easy to invest, but Chinese businesspeople were also attracted to Serbia because of its free-trade agreements with the EU, CEFTA and EFTA countries as well as Russia and Turkey (Lađevac et al., 2019, p. 60).

The first big project that followed after concluding the Strategic Partnership was the agreed construction of the Serbian-Chinese Friendship Bridge over the Danube River. ${ }^{6}$ The total worth of the project was EUR 170

\footnotetext{
${ }^{6}$ The new bridge was opened by Chinese Premier Li Keqiang and his Serbian counterpart Aleksandar Vučić on 18 December 2014. Although the official name of the bridge is Mihajlo Pupin's Bridge, it is also known as the China-Serbian Friendship Bridge or, the shortest, Chinese bridge.
} 
million, and as such, it was a capital project. The majority of the project EUR 145.5 million was financed by a loan from China's Exim Bank with a lowinterest rate of $3 \%$ and a grace period of 3-5 years.

This project was carried out by China's state-owned heavyweight China Road and Bridge Corporation (CRBC), while the participation of Serbian companies was contractually set to $45 \%$ of the value of the project. For the CRBC, this project had special value being its first project of this kind in Europe. By then, this company only had been active in the Asian and African markets.

\section{The Belt and Road Initiative and Sino-Serbian relations}

In 2013, Chinese President, Xi Jinping, proposed the 'One Belt, One Road' initiative as the form of an extension of sporadic smaller projects which China implemented along the ancient Silk Road route in the old days (Lađevac and Đorđević, 2016, p. 66). The financing of the project would be entrusted to new institutions - the Asian Infrastructure Investment Bank and the Silk Road Fund, as well as through new mechanisms to be established, and which would be supervised by the Shanghai Cooperation Organization.

As expected, this initiative caused different reactions. Some of them were positive, estimated that could enable the economic progress of countries on the route of the road, while others were negative. Behind such perception was the fear that China's enormous economic development accompanied by an enormous military budget could create a kind of security dilemma. There were a lot of them who also believed that behind the promotion of this project were hidden motives aimed to turn China into the main superpower (Lađevac and Đorđević, 2016, p. 66).

The same comments, if not even worse, caused China's decision to promote cooperation with the countries of Central and Eastern Europe, at first called $16+1$, later $17+1 .^{7}$ That project was even labeled as the Trojan horse in the EU yard (Đorđević and Lađevac, 2016, p. 63).

Serbia decided to enhance its relations with China, following the conclusion of the Strategic Partnership, by joining to the $16+1$ cooperation platform and the Belt and Road Initiative, as well. This decision had farreaching significance and contributed to the country's economic strength.

\footnotetext{
${ }^{7}$ First 16+1 Summit was held in 2012 in Warsaw, Poland.
} 
It is well known that Serbia has not yet recovered from the consequences of the turmoil events of the 1990s. Above that, the global economic crisis has limited the opportunities for attracting foreign investment. In that sense, the offer that came from China, not only to Serbia but to all the countries in our region, was timely and one would be irresponsible to reject it.

In the initial phase of cooperation between Serbia and China, all projects implemented in Serbia within the framework of the Initiative were criticized. Initially, projects were mainly in the field of infrastructure and energy, such as works on the Corridor XI, construction of the bridge on the Danube River, works on the construction of block three at the Kostolac Thermal Power Plant and similar (Zakić and Radišić, 2019). The main objections were that these projects were not investments, but strictly credit lines. As one might expect, critics have neglected the interest rate of these loans and the terms of their repayment. They were also prone to intentionally neglect the fact that either roads or bridges would remain in Serbia, and that citizens and the economy would multiply benefit from the upgraded capacities of the domestic energy sector (Lađevac, 2018, p. 60).

The Agreement on Economic and Technical Cooperation in Infrastructure Projects, also signed in 2009, gave an impetus to intensify economic relations, which resulted in reaching agreements on cooperation in several capital infrastructure projects in the Republic of Serbia among which the most significant is the Agreement on the Construction of the BelgradeBudapest railway.

Being situated on the Corridor $\mathrm{X}$, precisely at its $\mathrm{Xb}$ part, it will connect not only Belgrade and Budapest, but actually, the North Macedonia and Greece, connecting the Greek port of Piraeus with Central Europe and, at the same time, connecting the Middle East with Europe. Since the notable significance of this project recognized not only by Hungary and Serbia but also by China as a creator of the BRI, this idea was developed during the Summit within the framework of the $16+1$ cooperation held in Belgrade in December 2014. The three respective governments signed the Memorandum of Understanding and Cooperation on the Hungarian-Serbian Railway Project. Based on the MoU, the three parties agreed to conduct all necessary preparatory activities such as the work on a Feasibility Study, a detailed general agreement that defines the value of investments, contractor, contracting terms, etc. The project officially commenced by signing documents between the PR China, the Republic of Serbia and Hungary, on 25 December 2015 in Suzhou. The documents defined principles and models of joint cooperation and determined the sequence of further activities. 
In June 2017, at the trilateral meeting in Budapest, the Protocol on the reconstruction and modernization of the railway Belgrade - Budapest was signed. Statement of Hungarian Prime Minister Viktor Orbán at the opening of China-CEEC 16+1 summit hosted in Budapest on 27 November 2017, regarding issuing of a public tender for the Hungarian stretch of the Budapest-Belgrade rail line represented the fulfillment of the basic precondition to start working on this project on the Hungarian side as well. But, despite that, the project is moving extremely slowly. The European Commission continuously examines separate agreements signed by both Serbian and Hungarian authorities. The main focus is on Hungary, an EU member state that is subject to the full rigour of European procurement law. As a prospective member of the bloc, Serbia is subject to looser rules. Thanks to that fact, it is expected that Serbia would have fewer problems in project realization. It is obvious that the EU does not support partner relations between Serbia and China, but it is also true that apart from the usual politics of conditionality it will not introduce some other measures against Serbia, while Hungary's failure to comply with EU tender laws may be punished by fines and proceedings to reverse infringements. According to EU officials, the investigation was assessing the financial viability of $\$ 2.89$ billion and looking into whether it had violated European Union laws stipulating that the public tenders must be offered for large transport projects.

However, apart from projects funded through loans, the Belt and Road Initiative also offers direct investment projects.

The first example of different forms of investment represents the case of the Smederevo Steel Company. Like many other companies, this steel company has been in a major crisis since the dissolution of the SFRY. Previous attempts to privatize the company have been unsuccessful, so the first clue that a Chinese company might make the acquisition has been welcomed. In 2016, the acquisition was made by the HBIS Group. The value of this acquisition was $\$ 50$ million, with an additional investment commitment. Namely, the HBIS Group additionally has committed to retain almost 5,000 employees and modernize its production facilities. The business results that they reached were extremely high. According to the data for 2018, the Smederevo Steel Company is the largest Serbian exporter with an export value of EUR 749.5 million. As expected, the ironworks is constantly observed by the EU. To protect EU based manufacturers, the EU even introduced quota systems for third-country producers.

During 2018 one of the biggest news was that Serbia finally, and it proved to be successful, ended the multi decades-long problem with the Bor 
Mining and Smelter Basin. Precisely, China's Zijin Mining acquired a 63\% share in Bor Mining or, in specific figures, $\$ 1$ billion and 260 million. At the same time, Zijin also acquired rights to exploit copper deposits from the Canadian company Nevsun which decided to withdraw. Zijin took over all the deposits of Nevsun within only three days, paying about $\$ 1$ billion and 661 million. The estimated value of this site is approximately $\$ 100$ billion, which significantly increases the profitability of the Bor Mining itself. The realization of this project is immense when considering the fact that the Bor Mining and Smelter Basin employs 5,000 workers. Zijin pledged to keep all jobs in the first three years. However, given the expected growth in exploitation, a more likely scenario is the creation of additional working places that will eventually lead to the revival of eastern Serbia.

The trend of Chinese capital flow in the Republic of Serbia continued in 2019. At the end of March, Shandong Linglong opened a tire factory in Zrenjanin. A total of $\$ 900$ million has been invested in the construction of the factory, and it is initially planned to employ 1,500 workers, with the potential to further increase the number. Due to a production plan of 35,000 tires daily, or about 13 million per year, the company expressed its interest in investing in road construction in order to transport its products faster to its customers in Western Europe. Equally interesting is the fact that Shandong Linglong is interested in investing in the construction of a residential settlement in Zrenjanin for employees and factory management.

\section{CONCLUSION}

Apart from the challenges that inevitably follow each type of relation, the realized projects within the Belt and Road Initiative have positive records so far. Future perspective is even brighter, knowing that the establishment of cooperation was demanding by itself, considering disparities between China and Serbia. But the crucial point was obeying to the leading principles of the Belt and Road Initiative: joint discussion, co-construction and sharing; works on creating an open, inclusive, balanced and benefits-sharing framework of regional economic cooperation; practicing the new approach of sharing power and responsibility, as well as pursuing both benefit and righteousness.

The strict following of these principles will lead to the realization of the key objective of the BRI's 'five ways of connectivity': policy communication, infrastructure connection, smooth trade, accommodation of funds, peopleto-people connection. 
Still, Serbian stakeholders should bear in mind that Chinese partners are receptive to exceptional business ideas. Thus, there is a need for pushing forward domestic industrial transformations and upgrading, the necessity to overcome the role of plain consumer and take the role of innovator and manufacturer. Such change would naturally lead to a more open, inclusive and diversified type of cooperation that would easily assure stable finances and would even welcome third parties willing to invest.

\section{REFERENCES}

Dimitrijević, D. (2018). Odnosi Srbije i Kine na početku 21. veka [Relations Between Serbia and China at the Beginning of the XXI Century]. Medunarodni problemi, LXX(1), pp. 49-67.

Đorđević, B. \& Lađevac, I. (2016). Benefits and limitations of the 'One Belt One Road Strategy' in relations between China and the European Union: Serbian perspective. The Review of International Affairs, LXVII (1162-1163), pp. 57-69.

$\mathrm{Hu}$ Jintao Holds Talks with Serbian President Tadic. (2009, August 20), retrieved from http://rs.chineseembassy.org/eng/zsgx/zzjw/t5802 35.htm. Accessed 1 March 2020.

Joint Statement Between the Republic of Serbia and the People's Republic of China on Establishing Strategic Partnership. (2009), retrieved from http:/ / www.beijing.mfa.gov.rs/us.php. Accessed 1 March 2020.

Lađevac, I. (2008). Osnovne karakteristike saradnje Srbije i EU 2000-2008. godine [Characteristics of the Serbia-EU cooperation 2000-2008], in: E. Stojić Karanović \& S. Janković (Eds.), Elementi strategije spoljne politike Srbije [Elements of the Serbia's Foreign Policy Strategy] (pp. 54-68). Belgrade, Institute of International Politics and Economics.

Lađevac, I. (2008b). Ugovorni kapacitet Evropske unije na primeru Ugovora o stabilizaciji i pridruživanju sa Republikom Srbijom [European Union's Contractual Capacity on the Example of the Stabilization and Association Agreement with the Republic of Serbia]. Medunarodna politika, LIX(1132), pp. 11-20.

Lađevac, I. \& Đorđević, B. (2016). Possibilities for Promoting Interconnectivity between China and Central and Eastern European Countries. The Review of International Affairs, LXVII(1161), pp. 65-79.

Lađevac, I. (2018). Tekuća situacija i mogućnost koordinacije politike „Jedan pojas, jedan put" između Kine i EU: perspektiva Srbije [Current 
Situation and the Possibility of Coordinating the 'One Belt, One Way' Politics Between China and the EU: Serbia's Perspective], in: I. Lađevac (Ed.), Budućnost saradnje Srbije $i$ Kine [The Future of Cooperation Between Serbia and China] (pp. 45-59). Belgrade, Institute of International Politics and Economics.

Lađevac, I., Đorđević, B. \& Jović-Lazić, A. (2019). Serbian Views on '16+1' and 'Belt and Road' Initiative in China-EU relations, in: L. Zuokui \& I. Lađevac (Eds.), The Cooperation between China and Balkan Countries under the "Belt and Road" Initiative (pp. 54-70). Beijing, Institute of European Studies (IES).

Obradović, Ž. (2016). Strateško partnerstvo „male“ Srbije i „velike“ Kine: unutrašnji i međunarodni aspekti saradnje [Strategic Partnership Between 'Small' Serbia and 'Great' China: Domestic and International Aspects of Cooperation]. Srpska politička misao, 53(3), pp. 121-137.

Petranović B. (1988). Istorija Jugoslavije 1918-1988, Treća knjiga: Socijalistička Jugoslavija 1945-1988 [The History of Yugoslavia 1918-1988, Third book: The Socialist Yugoslavia 1945-1988]. Belgarde, Nolit.

Petrović D. \& Đukanović D. (2012). Stubovi spoljne politike Srbije - EU, Rusija, SAD i Kina: "Četiri stuba" spoljne politike Srbije - jedno viđenje [Serbia's Foreign Policy's pillars - EU, Russia, USA and China: 'Four pillars' of the Serbia's foreign policy - One View]. Belgrade, Institute of International Politics and Economics.

Zakić, K. \& Radišić, B. (2019). Influence of the Belt and Road Initiative on Chinese Investments in Europe, Case study: Balkan countries, in: L. Zuokui \& I. Lađevac (Eds.), The Cooperation between China and Balkan Countries under the "Belt and Road" Initiative (pp. 27-53). Beijing, Institute of European Studies (IES). 